\title{
Effect of Whole Body Vibration on Exercise Capacity and Quality of Life in Obstructive Lung Disease
}

\author{
WEAAM S. HASANEEN, M.Sc.*; SAMIR A. ALGAZZAR, Ph.D.****; EMAN R. EL-ADAWY, M.D.*** and \\ SAIFELDEEN A. RAGAB, Ph.D.*
}

The Department of Physical Therapy of Cardiopulmonary Vascular Disorder and Geriatric, Faculty of Physical Therapy* and Dean Physical Therapy Collage, Heliopolis University** and The Department of Chest, Faculty of Medicine, MUST University***

\begin{abstract}
Background: Skeletal muscle dysfunction in COPD deteriorate the symptoms and quality of life of patients. Exercise is a basic unit of Pulmonary rehabilitation causing improve muscle strength, exercise capacity, health status and reducing hospital readmission rate. Despite the benefits of exercise training, patients are not able to perform due to high levels of perceived dyspnea, fatigue, and fear of breathlessness. Whole-body vibration exercise have similar response produced by other modes of physical activity. This study aim to clarify the effect of Whole Body Vibration on exercise capacity andquality of life in COPD patients.
\end{abstract}

Aim of Study: To compare the effect of Whole Body Vibration to traditional exercise protocol on exercise capacity and quality of life with COPD patients.

Subject and Procedures: 30 COPD patients stage I \& II ( GOLD 2018) were assigned into two equal groups in number performed 3 session/week for 6 weeks. Group (A) received Squat exercises program on Whole Body Vibration 5-10 minutes with six series of 30s with 60s of rest between each series, and frequency $24 \mathrm{~Hz}$ in addition to traditional chest physiotherapy including Diaphragmtic breathing, cycling, strengthening for lower limbs while group (B) received the same training on the floorin addition to traditional chest physiotherapy before and after the 18th sessionsthe parameter of. Six minute walk distance test (6 MWDT), 5 repetition sit to stand test (5RSTS) and COPD assessment test (CAT) were also measured.

Results: In study group Group (A) showed significant increases in 6 MWDT, 5 RSTS and CAT, 27.36\%, 25.46\%, 36. $67 \%$ respectively \& in control group Group (B) showed significant increase $21.98 \%, 18.6 \%, 30.63 \%$ respectively, comparing between the two groups there were significant differences in 6 MWD and 5 RSTS, while non significant difference in CAT.

Conclusion: Whole Body Vibration training was good complementary training exercise, which improve ventilatory functions, enhances exercise capacity and quality of life for COPD patients.

Correspondence to: Dr. Weaam S.

Hasaneen,E-Mail: dr_mimo89@yahoo.com
Key Words: COPD - Whole body vibration - Exercise capacity.

\section{Introduction}

CHRONIC Obstructive Pulmonary Disease ( COPD) is a chronic respiratory condition that is often associated with multiple comorbidities. Among the extrapulmonary symptoms, skeletal muscle weakness and dysfunction are frequent and are associated with exercise intolerance and health status impairment in COPD patients, regardless of the level of airway obstruction [1,2].

The exercise training is the most effective currently available non-pharmacological treatment option for COPD [3]. There is increased evidence for the use and efficacy of a variety of exercise training as part of pulmonary rehabilitation in patients with COPD, including endurance and strength training, which have been associated with improvements in manifestations, exercise tolerance, and quality of life in COPD patients but ventilatory limitation with apparent muscle weakness in COPD patients limit their ability to perform exercise for long periods. So, choosing other mode of exercise such as whole body vibration has been proven to be more effective for COPD patients than constantload exercises [4].

Whole-Body Vibration (WBV) is a new exercisemodality done on a vibrating platform which stimulate muscle spindles producing muscle contractionswith physiological responses similar to those produced by other physical activity such as aerobic conditioning and strength training. Indicating that WBV training is an efficient strength training [5]. Recent reviews suggested that WBVT is helpful to COPD patients by improving their exercise capacity, without producing adverse effect

r6 71 


\section{Subjects and Methods}

This study was conducted from chest out-patient clinic and in-patient of the Chest Department at El-Kasr El-Aini Hospital. And received the intervention protocol for six successive weeks at the period from (September 2018 to March 2020). Thirty male with mild and moderate COPD according to (GOLD 2018) for more than three months.

Inclusion criteria: 30 male patients their age 45-60 were diagnosed as COPD for more than three months with no exacerbation in the last 3 months.

Exclusion criteria: Patients who had the following criteria were excluded from the study such as artificial joint replacement in the lower extremities, post bone fracture, history of deep vein thrombosis, clinical signs of a severe cardiac event and Neurological disorders. All patients, regardless of their health status were allowed to discontinue the training program and withdraw from the study at any time.

\section{Design of study:}

- Group (A): 15 patients received Squat exercises program onwhole Body Vibration for 6 weeks ( three sessions/weeks) in addition to traditional chest physiotherapy including (Diaphragmtic breathing), cycling, strengthening for lower limbs.

- Group (B): 15 patients who was received the same training on the floor in addition to traditional chest physiotherapy.

\section{Ethical committee:}

All participants signed a written informed consent prior to participation in the study approved by Research Ethical Committee, Faculty of Physical Therapy, Cairo University (No: P.T.REC/012/ 002043).

Evaluation process: The evaluation procedure had been done for both group patients.

1- Electronic Spirometer: Measuring pulmonary function by an electronic Spirometer (ModelSchiller AG, CH6304) FEV1, FVC, FEV1/FVC were measured in accordance with American Thoracic Society [ATS] [8] guidelines for confirming COPD. Measurements for all patients were performed once before initiating the study.

2- The COPDAssessment Testquestionnaire (CAT): [ 9-11] to measure the health status of patients with COPD.

3-Six minute walk distance test: [12] as a measure of functional exercise capacity.
4- Pulse oximeter: During 6 MWDT patients were monitored with a continues pulse oximetry to measure oxygen saturation (Model: YK-80A Power: DC3V, AAA (x2) built-in Made in China).

5- 5 repetition sit to stand test (5 RSTS): [13] it evaluates an individual's activity for daily living and measures the repetition of standing-up and siting down on a chair.

6- Weight and height scale to calculate BMI.

7- Stop watch to detect the time during 6 MWDT \& 5 RSTST.

\section{Treatment process:}

The program of the study had given 2 equal groups (A and $\mathrm{B}$ ) for 18th sessions training. The program was subdivided into:

1- Diaphragmatic breathing for both group: The patient was in the half lying position (bed in 45 degrees), the therapist put his hand below the rib cage of the patient (epigastric angle) the patient breathed in gently and fully through his nose letting his abdomen rise as the lungs fill with air, the patient held his breath for account of five (3-4sec) then the patient exhaled through his nose then repeat this exercise around 15 times per day by taking short rest in between a group of five sets.

2- Exercise trainingfor both group: Consisted of endurance training $15 \mathrm{~min}$ cycling 3 days per week for 6 weeks.

3- Squatting exercise: Group (A): Squatting on Whole body vibration (PS-CFM014, China) Patients exercised in a squatting position with $30^{\circ}$ of knee flexion, with their feet $28 \mathrm{~cm}$ apart with upper limbs holding the platform bars, performing six series of 30 s with 60 s of rest between each series. The vibratory stimulus was offered at frequencies $24 \mathrm{~Hz}$. $6 \mathrm{~mm}$ peak-to-peak amplitude all sessions of training were monitored and heart rate, and oxygen saturation were monitored before, during, and after the series. Group ( B): Squatting on the floor.

\section{Data analysis:}

All statistical measures were performed through the Statistical Package for Social Studies (SPSS) version 25 for windows.

- Descriptive statistics and unpaired $t$-test were conducted for comparison of the mean age, weight, height and BMI between both groups.

- Unpaired $t$-test test was conducted for comparison of CAT, 6 MWD and 5 RSTS variables between both groups. 
- Paired $t$-test was conducted for comparison between pre and post-treatment CAT, 6 MWD and5 RSTS variables in each group.

- The level of significance for all statistical tests was set at $p<0.05$.

\section{Results}

\section{1- General characteristics of the subjects:}

Table (1) represented the comparative of physical characteristic values between WBV and control groups. The statistical analysis by independent $t$ test revealed that no significant differences $(p>0.05)$ in values of physical characteristics (age, weight, height and BMI) between WBV and control groups.

Table (1): Comparison of physical characteristics mean values between WBV and control groups.

\begin{tabular}{|c|c|c|c|c|c|c|}
\hline & $\begin{array}{c}\text { Control Group } \\
X- \pm S D\end{array}$ & $\begin{array}{c}\text { WBV Group } \\
\text { X- } \pm \text { SD }\end{array}$ & MD & $\begin{array}{c}t- \\
\text { value }\end{array}$ & $\begin{array}{c}p- \\
\text { value }\end{array}$ & Sig. \\
\hline Age (years) & $51.13 \pm 5.1$ & $50.93 \pm 5.24$ & 0.2 & 0.1 & 0.91 & NS \\
\hline Weight (kg) & $79 \pm 8.01$ & $794+4+3$ & -0.4 & -0.17 & 0.86 & NS \\
\hline Height $(\mathrm{cm})$ & $168.4 \pm 2.47$ & & 0.34 & 0.36 & 0.71 & NS \\
\hline $\mathrm{BMI}\left(\mathrm{kg} / \mathrm{m}^{2}\right)$ & $27.93 \pm 3.46$ & $28.11 \pm 1.54$ & -0.18 & -0.19 & 0.85 & NS \\
\hline $\begin{array}{l}\text { SD : Standard } \\
\text { MD: Mean D }\end{array}$ & $\begin{array}{l}\text { Deviation. } \\
\text { ffference. }\end{array}$ & $\begin{array}{l}p \text {-value } \\
\text { NS }\end{array}$ & $\begin{array}{l}\text { : Proba } \\
: \text { Non }\end{array}$ & $\begin{array}{l}\text { Sigill } \\
\text { Sign }\end{array}$ & $\begin{array}{l}\text { value } \\
\text { cant. }\end{array}$ & \\
\hline
\end{tabular}

\section{2- Six minute walk distance test (6 MWDT):}

A- Within groups: As shown in (Table 2) comparing the mean values between pre-and post 6 MWD within each group. There were significant differences between pre-and post 6 MWD within group A \& B.

Table (2): Mean 6 MWD pre and post-treatment of the group $\mathrm{A}$ and $\mathrm{B}$.

\begin{tabular}{|c|c|c|c|c|c|c|c|}
\hline $\begin{array}{l}6 \text { MWD } \\
(\mathrm{m})\end{array}$ & $\begin{array}{c}\text { Pre } \\
\mathrm{X} \pm \mathrm{SD}\end{array}$ & $\begin{array}{c}\text { Post } \\
\mathrm{X} \pm \mathrm{SD}\end{array}$ & VID & $\begin{array}{c}\% \text { of } \\
\text { change }\end{array}$ & $\begin{array}{c}t- \\
\text { value }\end{array}$ & $\begin{array}{c}p- \\
\text { value }\end{array}$ & Sig. \\
\hline Group A & & $403.8 \pm$ & -86.74 & 27.36 & -12.03 & 0.0001 & $\mathrm{~S}$ \\
\hline Group B & $\begin{array}{l}48.47 .26 \\
\frac{1}{3} 6.18\end{array}$ & $\begin{array}{l}43.66 .26 \\
+48.26\end{array}$ & -66 & 21.98 & -10.09 & 0.0001 & S \\
\hline MD & 16.8 & 37.54 & & & & & \\
\hline$t$-value & 1.07 & 2.23 & & & & & \\
\hline$p$-value & 0.29 & 0.03 & & & & & \\
\hline Sig. & NS & $\mathrm{S}$ & & & & & \\
\hline$x^{-:}: N$ & & & & lue & & valu & \\
\hline $\begin{array}{l}\text { SD : Star } \\
\text { MD: } \mathrm{Me}\end{array}$ & Dif & $\begin{array}{l}\text { tion. } \\
\text { e. }\end{array}$ & & & on Sign & $\begin{array}{l}\text { t. } \\
\text { ficant. }\end{array}$ & \\
\hline
\end{tabular}

B- Between groups: As shown in (Table 2) comparing mean values of pre- and post 6 MWD between WBV and control groups. There was no significant difference in pre 6 MWD $(p=0.29 ; p$ $>0.05$ ) while, a significant difference in post 6 MWD $(p=0.03 ; p<0.05)$ between WBV and control group.

\section{3- Five repetition sit to stand test (5 RSTS):}

A- Within groups: As shown in (Table 3) comparing mean values between pre-and post-5 RSTS within each group. There were significant differences between pre-and 5 RSTS within WBV group $(p$ $=0.0001 ; p<0.05)$ and control group $(p=0.0001 ; p$ $<0.05)$.

Table (3): Mean 5 RSTS pre and post-treatment of the group A and B.

\begin{tabular}{|c|c|c|c|c|c|c|c|}
\hline $\begin{array}{l}\text { 5 RSTS } \\
(\mathrm{sec})\end{array}$ & $\begin{array}{c}\text { Pre } \\
X- \pm S D\end{array}$ & $\begin{array}{c}\text { Post } \\
X^{-} \pm \text {SD }\end{array}$ & MD & $\begin{array}{c}\% \text { of } \\
\text { change }\end{array}$ & $\begin{array}{c}t- \\
\text { value }\end{array}$ & $\begin{array}{c}p \text { - } \\
\text { value }\end{array}$ & Sig. \\
\hline Group A & $\begin{array}{l}17.4 \pm \\
3.56\end{array}$ & $\begin{array}{l}12.97 \pm \\
2.85\end{array}$ & 4.43 & 25.46 & 8.22 & 0.0001 & $S$ \\
\hline Group B & $\begin{array}{l}18.76 \pm \\
2.41\end{array}$ & $\begin{array}{l}15.27 \pm \\
2.17\end{array}$ & 3.49 & 18.60 & 19.83 & 0.0001 & S \\
\hline MD & -1.36 & -2.3 & & & & & \\
\hline$t$-value & -1.21 & -2.48 & & & & & \\
\hline$p$-value & 0.23 & 0.01 & & & & & \\
\hline Sig. & NS & S & & & & & \\
\hline $\begin{array}{ll}\mathrm{x}^{-} & : \mathrm{Me} \\
\mathrm{SD} & : \text { Sta } \\
\mathrm{MD} & : \text { Me }\end{array}$ & $\begin{array}{l}\text { lard De } \\
\text { Differe }\end{array}$ & $\begin{array}{l}\text { ation } \\
\text { ce. }\end{array}$ & & $\begin{array}{l}\text { value } \\
\text { S }\end{array}$ & $\begin{array}{l}\text { Probab } \\
\text { ignifi } \\
\text { : Non }\end{array}$ & nnificant. & \\
\hline
\end{tabular}

B- Between groups: As shown in (Table 3) comparing mean values of pre-and post 5 RSTS between WBV and controlgroups. There was no significant difference in pre 5 RSTS $(p=0.23 ; p$ $>0.05$ ) while, a significant difference in post-5 RSTS $(p=0.01 ; p<0.05)$ between WBV and control group.

\section{4- COPD assessment test (CAT):}

A- Within groups: As shown in (Table 4) comparing mean values between pre-and post CATwithin each group. There were significant differences between pre-and post CAT within WBVgroup $(p$ $=0.0001 ; p<0.05)$ and control group $(p=0.0001 ; p$ $<0.05)$.

Table (4): Mean CAT pre and post-treatment of the group A and $\mathrm{B}$.

\begin{tabular}{|c|c|c|c|c|c|c|c|}
\hline CAT & $\begin{array}{c}\text { Pre } \\
X- \pm S D\end{array}$ & $\begin{array}{c}\text { Post } \\
X- \pm S D\end{array}$ & MD & $\begin{array}{c}\% \text { of } \\
\text { change }\end{array}$ & $\begin{array}{c}t- \\
\text { value }\end{array}$ & $\begin{array}{c}p- \\
\text { value }\end{array}$ & Sig. \\
\hline Group A & $22.2 \pm$ & $14.06 \pm$ & 8.14 & 36.67 & 7.55 & 0.0001 & $\bar{S}$ \\
\hline Group B & $\begin{array}{l}6.03 \\
23.93 \pm \\
6.6\end{array}$ & $\begin{array}{l}3.12 \\
16.6 \pm \\
4.8\end{array}$ & 7.33 & 30.63 & 6.45 & 0.0001 & S \\
\hline MD & -1.73 & -2.54 & & & & & \\
\hline$t$-value & -0.75 & -1.71 & & & & & \\
\hline$p$-value & 0.45 & 0.09 & & & & & \\
\hline Sig. & NS & NS & & & & & \\
\hline $\mathrm{x}^{-} . \mathrm{M}$. & & & & 政 & bal & value. & \\
\hline $\begin{array}{l}\text { SD: Stan } \\
\text { MD: Mea }\end{array}$ & $\begin{array}{l}\text { ard De } \\
\text { Differ }\end{array}$ & $\begin{array}{l}\text { ation. } \\
\text { ce. }\end{array}$ & & & $\begin{array}{l}\text { ignifi } \\
\text { Ion S }\end{array}$ & $\begin{array}{l}\text { nt. } \\
\text { ificant. }\end{array}$ & \\
\hline
\end{tabular}

B- Between groups: As shown in (Table 4) comparing mean values of pre-and post CAT between WBV and control groups. There was no significant difference in pre CAT $(p=0.45 ; p>0.05)$ and no significant difference in post CAT $(p=0.09 ; p$ $<0.05$ ) between WBV and control group. 


\section{Discussion}

The results of this study for both group showed statistically significant difference in increasing exercise performance and quality of life, but whole body vibration group showed more significant improvement in mean difference that it can be used as an important component of pulmonary rehabilitation for COPD patients.

Our results agreed with Greulich et al., [14] who reported that the whole Body Vibration was showed significant increase in 6 MWDT and reduction in the testing time of siiting-to-standing from the chair measures after the WBV training program of $12-26 \mathrm{HZ}$ in exercising group rather than standard physiotherapy group indicating an improvement on exercise capacity and performance of daily activities.

In consistent with our results Neves CD et al., [ 15] found significant increase in exercise capacity ( 6 MWD) after the WBV training program frequencies progressively increased each 4 weeks beginning with 30 followed by 35 and $40 \mathrm{HZ}$ for 12 weeks in exercising group rather than no change in non exercising group.

Also, the current study comes in line with the result of a study by Gloeckl $\mathrm{R}$ et al., [16] that showed significant increase in 6 MWD and significant decrease in 5 RSTST in tested group rather than control one when using 24-26HZ for 3 weeks.

The studies of Pleguezuelos et al., [17] for 6 weeks and BrazJ'unior et al., [18] for 12 weeks after the WBV training program of $35 \mathrm{HZ}$, also show a more significant increase in $6 \mathrm{MWD}$ in exercising group compared with non exercising group that coincided with the results shown in this study.

Moreover, these results came in agreement with the results achieved by Xiaotian Y et al., [19] who reported that WBV is a safe and feasible treatment to improve functional capacity and quality of life when using $35 \mathrm{HZ}$ for 12 weeks in COPD patients.

Furthermore, the results of Sahli et al., [20] which compared WBV training using $27 \mathrm{HZ}$ for 12 weeks with resistance training showed significant improvement in functional capacity and quality of life in both groups with no differences between them.

Consistent with this study Furness $\mathrm{T}$ et al., [21] reported that was significant improvement in performance of ADLs (5 RSTS) in people with COPD after WBV program of $25 \mathrm{HZ}$.
These results going with the results of Nasrallah TM, et al., [13] who found significant decrease in 5 RSTS test after WBV intervention of 25-30HZ for 18 weeks in Egyptian COPD patients demonstrating that the 5 STS test is a good indicator tool in COPD patients.

In agreement with our results Spielmanns et al., [22] reported thattherewas significant improvement in CAT when trained on WBV in frequency of 24-26HZ for 3 months in COPD patients.

In accordance with these results, Greulich et al., [14] stated that WBV significantly improved CAT intraining group rather than control one when using 12-26HZ in COPD patients.

Also Gloeckl et al., [16] supported the use of WBV to improve functional performance of the lower limbs and QoL for COPD patients when received training program of $(24-26 \mathrm{~Hz})$ three times per week for 3 weeks.

From the above findings, it has been determined that Whole Body Vibration exercise was attributed to safety, tolerability and easy application causing better adherence and compliance thus the patients often feel better because they don't have to struggle to breathe and feel less fatigued, so improving quality of life and exercise tolerance.

\section{Conclusion:}

The Whole-Body Vibration Training (WBVT) was an alternative to conventional treatment for muscle strength and physical conditioning helped to increase exercise performance, muscle strength, and quality of life in patients with COPD. AddingWBVT to 30 squat exercises was well tolerated and did notfurther increase patient-related symptoms.

\section{References}

1- MIRAVITLLES M., PRICE D., RABE K.F., SCHMIDT H., METZDORF N. and CELLI B.: Comorbidities of patients in tiotropium clinical trials: Comparison withobservational studies of patients with chronic obstructive pulmonary disease. Int. J. Chron. Obstruct. Pulmon. Dis., 10: 549-64, 2015.

2- MATKOVIC Z., CVETKO D., RAHELIC D., ESQUINES, ZARAK M. and MIRAVITLLES M.: Nutritional status of patients with chronic obstructive pulmonary disease in relation to their physical performance. COPD, 14 (6): 626-34, 2017.

3- MALTAIS F., DECRAMER M., CASABURI R., BARREIRO E., BURELLE Y., DEBIGARÉ R., DEKHUIJZEN P. N., FRANSSEN F., GAYAN-RAMIREZ G., GEA J., GOSKER H.R., GOSSELINK R., HAYOT M., HUSSAIN S. N., JANSSENS W., POLKEY M.I., ROCA J., SAEY 
D., SCHOLS A.M., SPRUIT M.A., STEINER M., TAIVASSALO T., TROOSTERS T., VOGIATZIS I. and WAGNER P.D.: ATS/ERS Ad Hoc Committee on Limb Muscle Dysfunction in COPD. An official American Thoracic Society/European Respiratory Society statement: Update on limb muscle dysfunction in chronic obstructive pulmonary disease. Am. J. Respir. Crit. Care Med., 189: e15-e62, 2014.

4.- SÁ-CAPUTO D., GONÇALVES C.R., MOREL D.S., MARCONI E.M., FRÓES P., RUfiNO R., COSTA C.H., LOPES A.J., ARNÓBIO A., ASAD N.R., MARIN P.J., FURNESS T. and BERNARDO-FILHO M.: Benefits of whole-body vibration, as a component of the pulmonary rehabilitation, in patients with chronic obstructive pulmonary disease: A narrative review with a suitable approach. Evid Based Complement Alternat Med., 2016: 2560710, 7 pages, 2016.

5- ADRIANE B. CARDIM, M.Sc.; PATRÍCIA E.M. MARINHO, Ph.D.; JASIEL F. NASCIMENTO Jr., M.Sc.; HELEN K.B. FUZARI, M.Sc. and ARMÉLE DORNELAS De ANDRADE, Ph.D.: Does Whole-Body Vibration Improve the Functional Exercise Capacity of Subjects With COPD? A Meta-Analysis, Respiratory Care, Vol. 61 No. 11: 1552-9, 2016.

6- CARDIM A.B., MARINHO P.E., NASCIMENTO J.F. Jr., FUZARI H.K., DORNELAS De ANDRADE A.: Does whole-body vibration improve the functional exercise capacity of subjects with COPD? A meta-A meta-analysis. Respir. Care, 61: 1552-9, 2016.

7- GLOECKL R., HEINZELMANN I. and KENN K.: Whole body vibration training in patients with COPD: A systematic review. Chron. Respir. Dis., 12: 212-21, 2015.

8- CELLI B.R. and MAC NEE W.: Standards for the diagnosis and treatment of patients with COPD: A summary of the ATS/ERS position paper. Eur. Respir. J., 23: 932-46, 2004.

9- GULART A.A., MUNARI A.B., QUEIROZ A.P., CANI K. C., MATTE D.L. and MAYER A.F.: Does the COPD assessment test reflect functional status in patients with COPD? Chronic Respiratory Disease, Vol. 14 (1) 37-44, 2017.

10- MARC SPIELMANNS, TOBIAS BOESELT, RAINER GLOECKL, ANJAKLUTSCH, HENRIKE FISCHER, HENRYK POLANSKI, CHRISTOPH NELL, JAN H STORRE, WOLFRAM WINDISCH and ANDREAS.R. KOCZULLA: Development and first validation of the COPD Assessment Test. Eur. Respir J., 34 (3): 648-65, 2017.

11- MOHAMED S. AL-MOAMARY, F.R.C.P. (Edin), F.C.C.P., MOHAMED S. AL-HAJJAJ, M.D., F.R.C.P. (C), HANI M. TAMIM, M.P.H., Ph.D., MOHAMED O. ALGHOBAIN, M.D., F.C.C.P., HATEM A. AL-QAHTANI, S. B.I.M., M.D. and FAISAL A. AL-KASSIMI: The reliability of an Arabic translation of the chronic obstructive pulmonary disease assessment test (London) MRCPI, FRCP Saudi Med. J., Vol. 32 (10): 1028-33, 2011.

12- WILLIAM STRINGER and DARCY MARCINIUK: The Role of Cardiopulmonary Exercise Testing (CPET) in Pulmonary Rehabilitation (PR) of Chronic Obstructive Pulmonary Disease (COPD) Patients, COPD: Journal of Chronic Obstructive Pulmonary Disease, Volume 15, Issue 6621-631, 2018.
13- TAREK M. NASRALLAHA, ISMAIL M. ELWAKILB, HOSSAM EMAMC and ASHRAF ABDELSALAM AHMAD: Effects of Whole-Body Vibration on Egyptian Patients with Chronic Obstructive Pulmonary Disease: A randomized Controlled Trial ,International Journal of Medical Arts, 2 [2]: 420-6, 2020.

14- GREULICH T., NELL C., KOEPKE J., et al.: Benefits of whole body vibration training in patients hospitalised for COPD exacerbations-a randomized clinical trial. BMC pulmonary medicine, 14: 60, 2014.

15- NEVES C.D., LACERDA A.C., LAGE V.K., SOARES A.A., CHAVES M.G., LIMA L.P., SILVA T.J., VIEIRA É.L., TEIXEIRA A.L., LEITE H.R., MATOS M.A. and MENDONÇA V.A.: Whole body vibration training increases physical measures and quality of life without altering inflammatory-oxidative biomarkers in patients with moderate COPD. J. Appl. Physiol., 125: 520-8, 2018.

16- RAINER GLOECKL, INGA HEINZELMANN, SANDRA BAEUERLE, EVA DAMM, ANNA-LENA SCHWEDHELM, MERVE DIRIL, DAVID BUHROW, ANDREAS JERRENTRUP and KLAUS KENN: Effects of whole body vibration in patients with chronic obstructive pulmonary disease-a randomized controlled trial. Respiratory medicine, 106: 75-83, 2012.

17- PLEGUEZUELOS E., PÉREZ M.E., GUIRAO L., SAMITIER B., COSTEA M., ORTEGA P., et al.: Effects of whole body vibration training in patients with severe chronic obstructive pulmonary disease. Respirology, 18 (6): 1028-34, 2013.

18- DONATO S. BRAZJÚNIOR, ARMÉLE DORNELAS De ANDRADE, ANDREI S. TEIXEIRA, CLÉSSYO A. CAVALCANTI, ANDRÉ B. MORAIS, and PATRÍCIA E.M. MARINHO: Whole-body vibration improves functional capacity and quality of life in patients with severe chronic obstructive pulmonary disease (COPD): A pilot study. Int. J. Chron. Obstruct. Pulmon. Dis., 10: 125-32, 2015.

19- XIAOTIAN YANG, YUJING ZHOU, PU WANG, CHENGQIHE and HONGCHEN HE: Effects of whole body vibration on pulmonary function, functional exercise capacity and quality of life in people with chronic obstructive pulmonary disease: A systematic review; Clinical Rehabilitation, Vol. 30 (5): 419-43, 2016.

20- SALHI B., MALFAIT T.J., VAN MAELE G., JOOS G., VAN MEERBEECK J.P. and DEROM E.: Effects of whole body vibration in patients with COPD. COPD Journal, 12: 525-32, 2015.

21- FURNESS T., JOSEPH C., NAUGHTON G., WELSH L. and LORENZEN C.: Benefits of whole-body vibration to people with COPD: A community-based efficacy trial. BMC Pulm. Med., 14: 38, 2014.

22- MARC SPIELMANNSA, RAINER GLOECKLC, JANA MARIE GROPPA, CHRISTOPH NELL, ANDREAS REMBERT KOCZULLA, TOBIAS BOESELT, JAN HENDRIK STORRE and WOLFRAM WINDISCH: Whole-Body Vibration Training During a Low Frequency Outpatient Exercise Training Program in Chronic Obstructive Pulmonary Disease Patients: A Randomized, Controlled Trial, J. Clin. Med. Res., 9 (5): 396-402, 2017. 


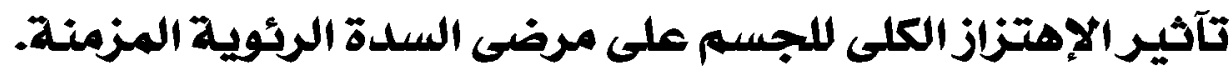

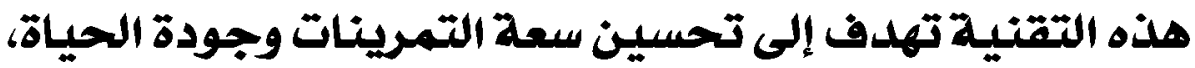 وتحسين وظائف الرئة}

الهدف من البحث: الفرض من هذه الدراسة هو تآثير الإهتزاز الكلى للجسم على مرضى السدة الرئوية المزمنة. هذه التقنية تهدف إلى

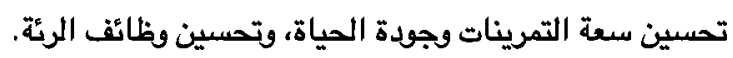

مواد وأساليب البحث: آجريت هذه الدراسة على ثلاثثف رجلاً يعانون من مرض الإنسداد الرئنى المزمن من قسم الصدر بمستشفى القصر

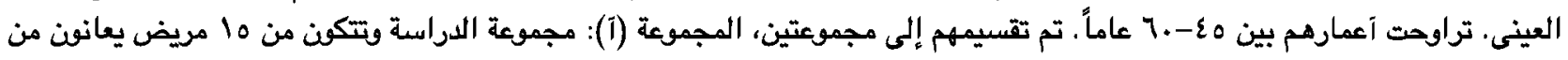

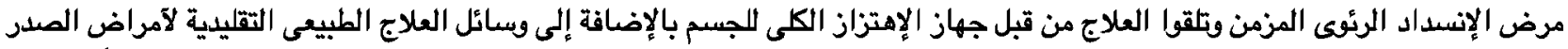

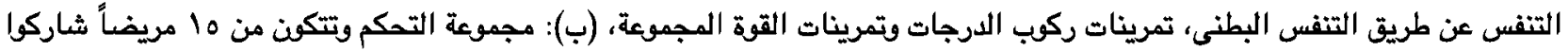

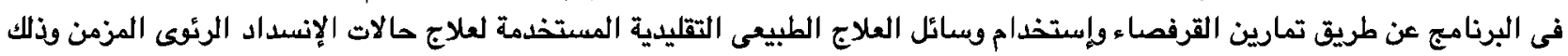

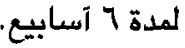

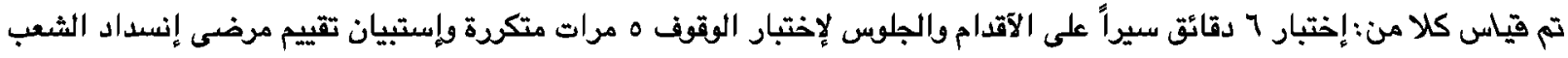

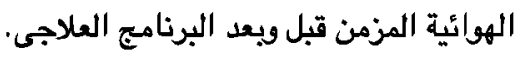

نتائج البحث: بعد إجراء التحليل الإحصائى آوضحت النتائج آن هناك زيادة ذات دلالة إحصائية وكانت النسب كالآتى: في المجموءة (i)

5 RSTST (18.6\%), 6 MWDT (21.98\%) ونسب المجموعة (ب) CAT (36.67\%), 5 RSTST (25.46\%), 6 MWDT (27.36\%)

.CAT $(30.63 \%)$, 